Ann. Biol. anim. Bioch. Biophys., I976, 16 (3), 457-464.

\title{
CHANGES IN SENSITIVITY OF PINEALOCYTE $\beta$-RECEPTORS DURING PRECOCIOUS SEXUAL MATURATION OR AFTER POSTNATAL STERILISATION WITH ESTROGEN IN THE FEMALE RAT
}

\author{
M. WILKINSON ( ${ }^{1}$ ), Joséphine ARENDT, D. de ZIEGLER and K. B. RUF \\ with the technical assistance of Willemina VAN DonselaAr and Madeleine VuILLeT \\ Département de Physiologie et Clinique universitaire de Pédiatrie, \\ Université de Genève, \\ École de Médecine
}

\section{SUMMARY}

The effects exerted on the $\beta$-receptors of the pineal gland of two types of experimental manipulation known to acutely modify hypothalamic function in the female rat have been investigated. The sensitivity of the pinealocytes towards norepinephrine was monitored by measuring $\mathrm{N}$-acetyl transferase activity as well as the production of melatonin. The use of a new radioimmunoassay for melatonin enabled us to carry out both determinations on the same gland obtained from in vivo experiments.

Firstly, unilateral electrochemical brain lesions, placed stereotaxically into the median eminence of 23 day old female rats leads to premature ovulation on day 27 or day 28 of life. We report here that this precocious maturation of the hypothalamic-gonadal axis is accompanied by a significant increase, first observable on day 26 , in the sensitivity of the pinealocyte $\beta$-receptors toward norepinephrine $\left(\mathrm{IO}^{-6} \mathrm{M}\right)$ in vitro.

Secondly, neonatal "sterilization " of female rats using estradiol benzoate (Ioo $\mu$ g per rat; day 4) known to lead to permanent neuroendocrine abnormalities in adulthood, also led to an increase in sensitivity of the pineal towards norepinephrine. By day 45 of life, norepinephrine stimulation of $\mathrm{N}$-acetyl transferase activity was significantly more effective in treated animals than in controls. This effect could still be observed at 90 days.

The mechanisms underlying these unexpected observations remain obscure.

\section{INTRODUCTION}

The rat pineal gland is now known to exhibit most of the properties of a steroid target organ. The gland is able to take up and concentrate, via specific protein receptors, the sex hormones estradiol, testosterone and progesterone. In this respect, and

(1) Address for correspondence : Fondation pour Recherches médicales, 64, Avenue de la Roseraie, I2II Genève 4 (Suisse). 
also in its ability to metabolise these steroids, the pineal has much in common with the hypothalamus (for references see Cardinali et al., I975 $a, b$;CARDINALI, I974). In addition both these structures have in common an adrenergic component which appears to be influenced by sex steroids (see CARDINALI et al., I975 $b$; GUNAGA et al., I974; WeISS and CraYTON, I970).

The aim of the present study was to investigate the possibility that pineal function may be altered concomitantly as a consequence of two modifications in hypothalamic function known to result from experimental manipulations involving estrogen. On the one hand, the placement of electrochemical lesions into the hypothalamus of immature female rats leads to precocious activation of the hypothalamo-pituitarygonadal axis via estrogen-feedback (for references see RUF et al., I974; I975). On the other, a single injection of estradiol benzoate, given to newborn female rats, is known to abolish permanently the cyclic gonadotrophin release mechanism normally present in the brain of mature female rats (Gorskr, rg63).

We chose to monitor the possible changes in pineal function, concurrent with changes in the hypothalamus, through the measurement of both serotonin $\mathrm{N}$-acetyl transferase (NAT) activity and melatonin production. In the rat, NAT is the ratelimiting enzyme which controls the biosynthesis of melatonin. The in vivo activity of NAT is darkness-induced and is 15 to 70 -fold higher at night than in the day (KLEIN and WELLER, I970). This elevation is controlled, via a $\beta$-adrenergic receptor, by norepinephrine released from sympathetic nerve terminals (for reference see ROMERo et al., I975). Norepinephrine is also able to activate NAT in cultured pineals (see, for example, Romero et al., I975).

Thus, we have studied the effect on NAT activity of a stimulatory concentration $\left(\mathrm{IO}^{-6} \mathrm{M}\right)$ of norepinephrine on cultured pineals removed from both lesioned and sterilized animals, together with their controls. In addition, we have measured both NAT activity and melatonin from lesioned animals killed three hours after the onset of the dark period. The correlation of NAT activity and melatonin production, in the same pineal, was made possible by the development of a radioimmunoassay for melatonin (ARENDT et al., r975).

\section{MATERIALS AND ME'THODS}

\section{Lesion experiments}

Female rats of a Sprague-Dawley-derived strain (SIV-5o) and of certified age were obtained from the Institute for Veterinary Medicine, University of Zürich, on day 21 of life. They were caged in groups of 6 or 8 and housed under controlled lighting conditions (lights on from o7oo $\mathrm{h}$ to $1900 \mathrm{~h}$ ). In order to improve the accuracy of stereotaxic electrode placement, only animals which had reached a body weight of $\geqslant 56 \mathrm{~g}$ on day 23 were used for experiments; these rats represented a selection of approximately the top Io p. Ioo of the weight distribution found in this population under the breeding conditions used. Unilateral electrochemical stimulation of the basal hypothalamus, by passage of a direct current (o.5 mA, I5 s) through a stainless steel electrode, was carried out as previously described (RuF et al., 1974) on day 23 .

For the in vitro studies groups of animals were killed by decapitation at various times after the placement of the lesion i.e. I hr post-operatively (day 23 of life) and on subsequent days at I0.00 h (day 24-day 27). Pineal glands were rapidly dissected (approx. 30 secs) and placed directly into a culture medium (see below) containing ${ }^{-6} 0^{-6} \mathrm{M}$ norepinephrine (Bitartrate ; Sigma.) Two to three pineals were placed in one culture dish (LUX Scientific, Thousand Oaks, Calif. 9r36o; 
$60 \times$ I $5 \mathrm{~mm}$ ) containing I. $5 \mathrm{ml}$ of medium. The culture medium was NCTC I35 (Gibco) containing additional glucose (500 $\mathrm{mg}$ p. roo), sodium pyruvate ( $\mathrm{r} \mathrm{mM}$ ), MEM non-essential amino acids (Gibco), bovine serum albumin ( $1 \mathrm{mg} / \mathrm{ml}$; Sigma), penicillin/streptomycin (25 units per $\mathrm{ml}$; Gibco) and ascorbic acid (o. $\mathrm{m} \mathrm{mg} / \mathrm{ml}$ ). Pineals were cultured for $3 \mathrm{hr}$ at $37^{\circ}$ under water saturated 95 p. 100 air $/ \mathrm{CO}_{2}$.

Pineals were removed from culture and immediately assayed for NAT using the method of DEGUCHI and AXELROD (1972) but employing $20 \mathrm{nMol}$ of $\left({ }^{14} \mathrm{C}\right)$-acetyl coenzyme A (4.42 $\mathrm{mCi} / \mathrm{mMol}$; Amersham) per pineal.

For the night experiments the animals (lesioned plus non lesioned controls; days 26 to 28 of life) were killed under red light $3 \mathrm{hrs}$ after the onset of darkness $(22.00 \mathrm{hrs})$. The pineals were homogenised in phosphate buffer $(50 \mu 1 ; 0.05 \mathrm{M} ; \mathrm{pH} 6.6)$ and immediately assayed for NAT, usually within $48 \mathrm{hrs}$. An aliquot of this homogenate (Io $\mu \mathrm{l}$ ) was diluted in o.I M phosphate buffer to $I 20 \mu \mathrm{l}$ and of this solution $20 \mu \mathrm{l}$ was used for the melatonin assay (ARENDT et al., I975).

\section{"Sterilization" experiments}

The female rats used in this series of experiments were of the same strain as described above, but were born and reared on the premises. On day 4 of life, the animals were pooled, divided into two groups of equal size (usually 8) and one half was injected with estradiol benzoate (roo $\mu \mathrm{g}$ in $50 \mu l$ of peanut oil ; s.c.). Animals were sacrificed on days $23,45,65$ and 90 of life. Pineals were cultured and stimulated as described above.

\section{Statistics}

$p$ values were calculated by Student's $t$ test (2-tailed).

\section{RESULTS}

\section{r. - Lesion experiments in vitro}

Activities of NAT, measured after stimulation with ro $^{-6} \mathrm{M}$ norepinephrine, are shown in figure $I$ and are represented in c.p.m. The c.p.m. value is directly proportional to enzyme activity ; the quenching coefficient in this assay was determined to be constant at 80.7 p. Ioo. Thus, the c.p.m. value represents NAT activity per pineal per 15 min. Clearly, on days 26 and 27 the pineals from lesioned animals are significantly more sensitive to norepinephrine than those from control animals.

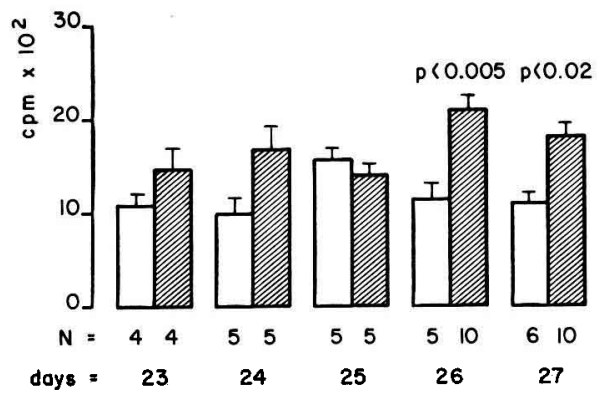

FIG. I. - Effect of a hypothalamic lesion (day 23) on $\mathrm{N}$-acetyl transferase (NAT) activity in vitro stimulated by norepinephrine $\left(\mathrm{ro}^{-6} \mathrm{M}\right)$

Activity, in c.p.m., per pineal per $15 \mathrm{~min}$

open bars $=$ controls $; \mathrm{N}=$ number of animals; Means $= \pm \mathrm{SEM}$ 


\section{2. - Lesion experiments in vivo}

It was thought desirable to investigate whether the increase in sensitivity of the pineal to norepinephrine in vitro, as a result of the brain lesion, was also reflected in the in vivo situation $i . e$. would the endogenous rise in NAT observed after darkness be higher in lesioned animals? In addition, we wanted to know whether the lesioned animals could produce more melatonin in response to an increase in NAT activity. Figure 2 illustrates that on day 27 the lesioned animals have a significantly higher NAT activity (fig. 2 B) compared with controls as well as a higher melatonin content (fig. 2 A). NAT and melatonin estimations were carried out on the same pineal. In experiments in which the lesioning was inefficient, as judged by an absence of early vaginal opening, both NAT and melatonin values were indistinguishable between lesioned animals and controls on days 26-28 (results not shown).

The c.p.m. values in figure 2 are proportional to NA'T activity per pineal per $20 \min$.

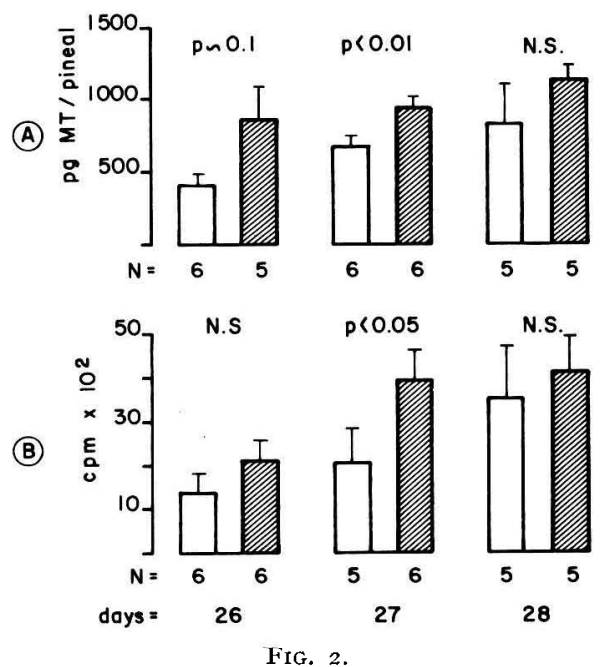

A) Effect of a lesion (day 23) on melatonin (MT) content of the pineal at $2.2 .00 \mathrm{~h}$ in $p g$ melatonin per pineal.

B) Corresponding NAT activity measured in same pineals. Activity per pineal per $20 \mathrm{~min}$ open bars $=$ controls

\section{3. -- Sterilized animals in vitro}

All animals injected with estradiol benzoate (Ioo $\mu \mathrm{g}$ ) showed early vaginal opening (before day $2 \mathrm{I}$ ). The mean age of vaginal opening in control rats was approximately 37 days. However, since estrogen sterilized rats do show a cyclic variation in vaginal smear, ovarian weights were taken to be a more reasonable measure of the incidence of sterility (see GoRSKI, I963; MALLAMPATI and Johnson, I974).

Ovarian weights of less than one half of control weights were taken to indicate sterility, The body weights of the two groups were never significantly different $(p>0.2)$. 
Figure 3 (c.p.m. here equivalent to NAT activity per pineal per $\mathrm{I}_{5} \mathrm{~min}$ ) illustrates the significantly higher NAT activity shown by pineals from sterile animals (45-90 days old) as compared with controls, after stimulation with $10^{-6} \mathrm{M}$ norepinephrine (animals sacrificed at approximately $13.00 \mathrm{~h}$ ). Careful smearing of control animals did not indicate that NAT activity was related to the stage of the estrous cycle (results not shown).

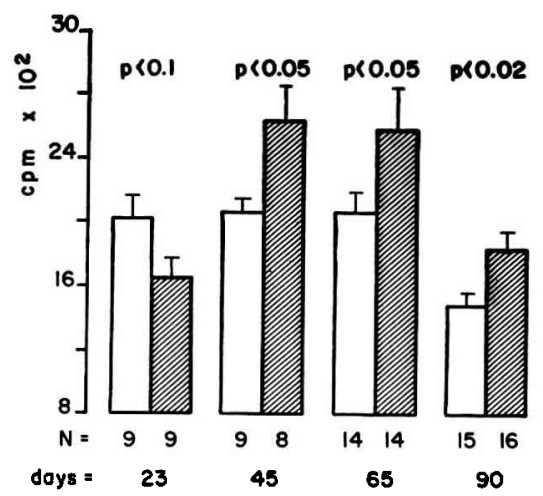

FIG. 3. - Effect of sterilization with estradiol benzoate on NAT activity in vitro stimulated by norepinephrine (10-6 $\mathrm{M}$ )

Activity per pineal per 15 min open bars $=$ controls

\section{DISCUSSION}

The results of the experiments described here, despite the limited number of animals involved, indicate that pinealocyte $\beta$-receptors appear to be responsive to functional changes in the hypothalamus. We believe that these hypothalamic changes, though of opposite character, are both brought about by estrogen (GorskI, I963; RUF et al., I975). That is, the precocious activation of the gonadotropin surge mechanism after lesioning contrasts sharply with the abolition of this same mechanism by estrogen, in sterilized female rats. Paradoxically, we have now shown that as a result of both experimental manipulations the pineal becomes somewhat more sensitive to norepinephrine. A further point of interest concerns our observation of an increase in melatonin production, albeit transient, during precocious sexual maturation, since melatonin has long been considered to be antigonadotropic (see REITER, 1973).

Recent studies (CARDINALI et al., I975 $a, b$ ) have indicated that chronic treatment of ovariectomized rats with estradiol leads to an increase of norepinephrine turnover within the pineal gland, though not to an increase in pineal concentration of the neurotransmitter. This increase in activity of the neurons innervating the pineal could conceivably lead to elevated NAT levels. We have described elsewhere that the electrochemical lesion, applied on day 23 , leads to a sustained increase in ovarian production of estrogen (RUF et al., I974). This provides one possible explanation for the observed increased levels of NAT, taking into account the work of CAR- 
DINALI et al. $(1975 b)$ on the increase in neuronal activity stimulated by estrogen. However, this would not account for the increases in NAT noted after stimulation with exogenous norepinephrine in vitro. Moreover, it has been demonstrated (WEISS and CRAYTON, I970) that increases in plasma estrogen, on the morning of proestrous, actually inhibit the response of pineal adenylcyclase to norepinephrine.

We conclude therefore, that in the face of high and probably inhibitory levels of estradiol the lesion itself may remove a second, unknown, inhibition.

We have also observed an increase in sensitivity to norepinephrine in vitro, of pineals from estrogen sterilized animals. NAT levels were significantly higher than control values even at 90 days of age. So far, we have not measured melatonin output. Fstrogen levels in estrogen-sterilized rats are known to be slightly higher than those assayed at proestrous in normal cycling animals (MAL,LAMPATI and JoHNSON, I974), which would lead us to expect an inhibition of pineal response to $\beta$-stimulation. That this is not the case led us to consider the work of BROBERG et al. (I974) who describe a significant reduction in norepinephrine levels, after sterilization, in the peripheral adrenergic nerves innervating the rat uterus. It is known that depletion of pineal norepinephrine leads to supersensitivity of the $\beta$-receptors (DEGUCHI and AxELROD, I973). It remains to be determined whether the sympathetic nerves of the pineal are also sensitive to depletion by sterilization.

One further difficulty in the interpretation of our results lies in the observation that the pineal of animals undergoing precocious sexual maturation produce more melatonin during the dark period than control animals. We do not know whether this transient increase in pineal content has any influence on melatonin levels elsewhere. It is known, however, that brain and plasma levels of melatonin in chickens increase in parallel with pineal content during the dark phase of the lighting cycle (PANG et al., I974; PELHAM et al., I972). Nevertheless an increase in melatonin output by the pineal, a process normally thought to be antigonadotropic (REITER, I973) appears to be at odds with the observed attainment of precocious gonadal maturity in our animals. However, recent studies in the hamster (REITER et al., I974 ; TUREK et al., 1975) indicate that under certain conditions low doses of melatonin may be progonadotropic. Thus, the results presented here would suggest that melatonin is acting in concert with the lesion in providing the drive necessary for precocious sexual maturation. On the other hand, an increase in melatonin levels may be acting to slow down or modulate the drive initiated by the lesion. Pinealectomy is known to result in earlier vaginal opening in immature female rats, an effect blocked by melatonin administration (see CARDINALI, I974, for references). It will be of interest therefore to study the effect of lesions in pinealectomized animals. An additional explanation for the increase in pineal melatonin observed in the lesioned animals is the possibility that this elevation is only an apparent one, generated by a phaseshift in hydroxyindole-O-methyl transferase activity. This has recently been observed by WALLEN and YOCHIM (I974).

In our opinion the changes in pineal adrenergic function resulting from manipulations of hypothalamic function by estrogen are worthy of further study. The possible interaction between norepinephrine and estrogen at the level of the pineal could well clarify a similar complex interplay within the hypothalamus. 


\section{ACKNOWLEDGEMENTS}

This work was supported by grant no. 3.016.73 from the Swiss National Science Foundation and by a subsidy from the Société Académique de Genève.

Also gratefully acknowledged are grants-in-aid from the Frankfeld Foundation, Geneva, and the Emil Barell Foundation, Basel, for the purchase of a beta scintillation counter.

\section{RÉSUMÉ}

\section{MODIFICATIONS DE LA SENSIBILITÉ DES RÉCEPTEURS $\beta$ DES PINÉALOCYTES}

DANS LA MATURATION SEXUELLE PRÉCOCE OU APRÈS STÉRILISATION POSTNATALE, PAR UN ESTROGÈNE CHEZ IA RATTE

Nous avons étudié l'effet produit sur les récepteurs $\beta$ de la glande pinéale par deux manipulations expérimentales connues pour induire des modifications fonctionnelles de l'hypothalamus.

La sensibilité des pinéalocytes à l'égard de la noradrénaline a été suivie en mesurant l'activité de la $\mathbf{N}$-acétyl transférase ainsi que la production de mélatonine.

Le dosage radjoimmunologique de la mélatonine nous a permis de pratiquer ces deux déterminations sur une même épiphyse obtenue à partir d'expériences in vivo.

Des lésions électrochimiques unilatérales localisées stéréotaxiquement chez des rattes de $23 \mathrm{j}$ induisent une ovulation prématurée le $27^{\mathrm{e}}$ ou le $28^{\mathrm{e}}$ jour. Dans la première expérience, nous avons constaté que la maturation précoce de l'axe hypothalamo-gonadique est accompagnée d'une augmentation significative de la sensibilité des récepteurs $\beta$ des pinéalocytes à la noradrénaline ; cette augmentation devient apparente dès le $26^{\mathrm{e}}$ jour.

Dans le $2^{e}$ cas, des rattes ont reçu une injection néonatale de benzoate d'oestradiol (roo $\mu \mathrm{g} / \mathrm{rat}$ au $4^{\mathrm{e}}$ jour) induisant des modifications neuroendocriniennes permanentes à l'âge adulte, accompagnées de stérilité.

Nous avons à nouveau trouvé une augmentation de la sensibilité de la glande pinéale à la noradrénaline ajoutée in vitro: au $45^{\mathrm{e}}$ jour de vie la stimulation de l'activité de la N-acétyltransférase par la noradrénaline s'est révélée beaucoup plus efficace chez les animaux traités que chez les contrôles. Cette différence est encore observable à 90 jour.

Les mécanismes auxquels répondent ces observations inattendues demeurent incompris.

\section{REFERENCES}

Arendt J., Paunier L., Sizonenko P. C., 1975. Melatonin radioimmunoassay. J. Clin. Endocr. Metab., 40, 347-350.

Broberg A., Nybeli G., Owman Ch., Rosengren E., Sjöberg N.-O., I974. Consequence of neonatal androgenisation and castration for future levels of norepinephrine transmitter in uterus and vas deferens of the rat. Neurorendocrinology, 15, 308-312.

Cardinali D. P., Nagle C. A., Rosner J. M., I975 a. Control of estrogen and androgen receptors in the rat pineal gland by catecholamine transmitter. Life Sci., 16, 93-106.

CARDinali D. P., I974. Melatonin and the endocrine role of the pineal organ, 107-1 28, in : Current Topics in Experimental Endocrinology, 2, Academic Press, New York.

Cardinali D. P., Nagle C. A., Gomez E., Rosner J. M., I975 b. Norepinephrine turnover in the rat pineal gland. Acceleration by estradiol and testosterone. Life Sci., 16, I717-r724.

Deguchi T., Axelrod J., I972. Sensitive assay for serotonin N-acetyl transferase activity in rat pineal. Anal. Biochem., 50, 174-179.

Deguchi T., AxELRod J., I973. Supersensitivity and subsensitivity of the $\beta$-adrenergic receptor in pineal regulated by catecholamine. Proc. Nat. Acad. Sci., U.S. A., Y0, 24I I-2414.

GoRsKr R. A., I963. Modification of ovulatory mechanisms by postnatal administration of estrogen. Amer. J. Physiol., 205, 842-844. 
Gunaga K. P., Kawano A., Menon K. M. J., I974. In vivo effect of estradiol benzoate on the accumulation of CAMP in the rat hypothalamus. Neuroendocrinology, 16, 273-28r.

KleiN D. C., Weller J. L., I97o. Indole metabolism in the pineal gland: a circadian rhythm in NAT. Science, 169, 1093-1095.

Mallampati R. S., Johnson D. C., I974. Gonadotropins in female rats androgenized by various treatments. Neuroendocrinology, 15, 255-266.

Pang S. F., Ralph C. L., Reilly D. P., I974. Melatonin in chicken brain : origin, diurnal variation and distribution. Gen. Comp. Endocr., 22, 499-506.

Pelham R. W., Ralph C. L., Campeell J. M., 1972. Mass spectral identification of melatonin in blood. Biochem. Biophys. Res. Comm., 46, 1236.

Reiter R. J., Vaughan M. K., Blask D. E., Johnson L. Y., I974. Melatonin : its inhibition of pineal antigonadotrophic activity in male hamsters. Science, 185, II69-II7I.

Reiter R. J., I973. Comparative physiology: Pineal gland. Ann. Rev. Physiol., 35, 305-328.

Romero J. A., ZATZ M., AXELRod J., I975. $\beta$-adrenergic stimulation of pineal N-acetyltransferase : Adenosine $3^{\prime}: 5^{\prime}$-cyclic monophosphate stimulates RNA and protein synthesis. Proc. Nat. Acad. Sci. U.S.A., 72, 2107-2III.

Ruf K. B., Younglai E. V., Holmes M. J., I974. Induction of precocious sexual maturation in female rats by electrochemical stimulation of the brain. Brain Res., 78, $437-446$.

Turek F., Desjardins C., Menaker M., 1975. Biphasic effect of melatonin on the testis. Endocr. Soc. 57th Meeting, Abstr., No 597.

WALlen E. P., Yochim J. M., I974. Rhythmic function of pineal hydroxyindole-O-methyl transferase during the estrous cycle : An analysis. Biol. Reprod, 10, 46r-466.

Weiss B., CRAYToN J., I970. Gonadal hormones as regulators of pineal adenyl cyclase activity. Endocrinology, 87, 527-533. 